\title{
Spatial variation in Posidonia oceanica structural, morphological and dynamic features in a northwestern Mediterranean coastal area: a multi-scale analysis
}

\author{
E. Balestri* , F. Cinelli, C. Lardicci \\ Dipartimento di Scienze dell'Uomo e dell'Ambiente, Via Volta 6, 56126 Pisa, Italy
}

\begin{abstract}
Knowledge of the natural pattern of spatial variation of the variables of interest is fundamental for designing effective sampling strategies to be used in surveys and monitoring programs. Unfortunately, little is known on patterns of spatial variation of structural, morphological and dynamic features of Posidonia oceanica, despite their increasing use as indicators of the status and/or trend of meadows. Here, variations in some such features (such as shoot density, leaf biometry, annual rhizome elongation and leaf formation) were examined on a hierarchy of spatial scales, ranging from $\mathrm{cm}$ within individual meadows, to meadows separated by $10 \mathrm{~km}$, using independent full-nested analyses of variance. Overall, at least 3 variables showed significant variations in the mean values on each of the scales examined. Patterns of variability differed among individual traits. Most of the total variation, however, was on the smallest spatial scale examined (i.e. among replicates, shoots or quadrats). For some variables, a significant variation was also associated with the largest scale (i.e. among meadows). Collectively, the results indicated that patchiness in density, morphology and growth exists on a very local scale within P. oceanica meadows along the same isobath. This suggests that sampling designs and analyses which incorporate different spatial scales and appropriate replications should at least be considered in the future when planning large-scale and long-term surveys.
\end{abstract}

KEY WORDS: Morphological variations $\cdot$ Nested designs $\cdot$ Seagrasses $\cdot$ Spatial scales

\section{INTRODUCTION}

The seagrass Posidonia oceanica L. Delile forms dense, often monospecific, meadows that may extend over $\mathrm{km}$-wide areas of the Mediterranean Sea, from the surface to about $40 \mathrm{~m}$ depth (Pérès \& Picard 1964). Because of its ecological importance (Romero et al. 1992) and vulnerability to a variety of anthropogenic influences, including pollution, turbidity and sedimentation (Ardizzone \& Pelusi 1984, Augier et al. 1984, Bourcier 1989, Peirano \& Bianchi 1995), there is increasing interest in using this species as an 'indicator' of health of Mediterranean coastal systems (Pergent et al. 1995, Marbà \& Duarte 1997, Guidetti 2001). In several countries, marine water-quality programs, includ- ing those concerning environmental impact, have recently included the evaluation of ecological status and/or trends of $P$. oceanica meadows, along with traditional water-analysis parameters (Benedito et al. 1990, Boudouresque et al. 1990, Pergent 1991, Fresi \& Dolce 2001). Assessment of the status of $P$. oceanica meadows is commonly based on the monitoring of a set of structural, morphological and dynamic variables. Although considerable efforts have been made to standardise methods and protocols, there is still little guidance on how to design and implement surveys and monitoring programs. Many studies and monitoring programs are currently performed by extrapolating data from shoots collected at random at 1 selected site (sometimes called the station area) and quadrats (5 to 
10 quadrats, 0.16 to $0.25 \mathrm{~m}^{2}$ ) placed randomly over the site, or along a depth gradient within meadows (Pergent-Martini et al. 1994, Alcoverro et al. 1995, Pergent et al. 1995, 1999, Guidetti \& Fabiano 2000), even though the validity of this practice has not been assessed.

A primary recommendation for designing effective seagrass surveys, monitoring programs and impact assessments is, that they should be based on appropriate spatial sampling schemes (Inglis \& Lincoln Smith 1995, Burdick \& Kendrick 2001). This requires knowledge of the scale at which there is consistent and predictable spatial variation in the variables of interest (Lewin 1992, Underwood 1993). Increasing evidence indicates that in heterogeneous habitats both growth and morphology of plants are dependent on the spatial scale of environmental heterogeneity (Wijesinghe \& Hutchings 1997). Although the existence of patchiness in density and phenology within Posidonia oceanica meadows has long been recognised (Panayotidis 1981), few studies have specifically addressed questions regarding the spatial patterns of a natural variation in the variables used to assess the ecological status of P. oceanica meadows. Available studies have focused on variations on a geographical scale (e.g. among meadows along latitudinal gradients) or within meadows across depths (e.g. shallow vs deep stands; Pergent-Martini et al. 1994, Alcoverro et al. 1995, Marbà et al. 1996, Marbà \& Duarte 1997, Zupo et al. 1997). No studies have examined variations at different spatial scales within a meadow at a given depth; therefore, it is unknown if the depth gradient is the only relevant source of within-meadow variation. However, $P$. oceanica is exposed not only to variations in environmental conditions according to water depth gradients or biogeographical processes, but also to considerable, often unapparent, variations in topography, substrate type, resource availability (nutrients, light quality and incidence), and an extensive range of biological and physical disturbances, from small to large scales, similar to other seagrasses (Patriquin
1975, Duarte 1991, Marbà et al. 1994, Robbins \& Bell 1994, Marbà \& Duarte 1995, Turner et al. 1996, Fonseca \& Bell 1998, Townsend \& Fonseca 1998). Because of horizontal expansion and exploratory growth, different modules of $P$. oceanica can be located in sites of differing environmental quality. Since many seagrasses have the potential to adjust their form and function to the immediate environment (Erftemeijer \& Herman 1994, van Tussenbroek 1995), it may be expected that some $P$. oceanica traits (such as branching frequency, number of leaves, length of leaves and internodes) will vary according to the spatial scale of heterogeneity, similarly to findings for terrestrial clonal plants (Wijesinghe \& Hutchings 1997). With such site-to-site variation, accurate estimation of the status and trends of a $P$. oceanica meadow could become highly complex.

Here, a hierarchical sampling design was employed: (1) to examine patterns of variability of some structural, morphological and dynamic variables used to assess the status of Posidonia oceanica meadows (e.g. shoot density, leaf biometry and derived indices, annual rhizome elongation rate and leaf formation) over a variety of scales, ranging from $\mathrm{cm}$ within meadows to $10 \mathrm{~s}$ of $\mathrm{km}$ among meadows; and (2) to identify the scale on which there was important variation. The study was conducted along the same isobath to permit recognition of variations which cannot be related to depth gradients.

\section{MATERIALS AND METHODS}

The study was conducted along the coast of Tuscany (NW Mediterranean, Italy) at 3 localities each separated by about $10 \mathrm{~km}$; Rosignano Solvay $\left(43^{\circ} 22^{\prime} \mathrm{N}\right.$, $\left.10^{\circ} 26^{\prime} \mathrm{E}\right), \mathrm{Cecina}^{\circ}\left(43^{\circ} 18^{\prime} \mathrm{N}, 10^{\circ} 29^{\prime} \mathrm{E}\right)$ and Calafuria $\left(43^{\circ} 30^{\prime} \mathrm{N}, 10^{\circ} 20^{\prime} \mathrm{E}\right)$. The localities were selected to provide 1 set of all possible sets of locations in this region that support well-developed Posidonia oceanica meadows. Descriptions of these meadows have been provided in a previous study (Cinelli \& Piazzi 1991). The sampling design focused on variability on 5 spatial scales, ranging from metres within each meadow to 10 s of $\mathrm{km}$ among the meadows (Fig. 1). In each meadow, 3 sites separated by 100s of $\mathrm{m}$ (200 to $300 \mathrm{~m}$ ) were randomly chosen along the same isobath (9 to $10 \mathrm{~m}$ ). In each site, 2 areas of approximately $50 \mathrm{~m}^{2}$ and 15 90 to $20 \mathrm{~m}$ apart were randomly selected. In each area, five $0.25 \mathrm{~m}^{2}$ quadrats separated by at least $1 \mathrm{~m}$ were randomly chosen. Finally, in each quadrat, 5 replicate orthotropic shoots of $P$. oceanica were randomly sampled and fixed in 5\% formalin in sea-
Fig. 1. Posidonia oceanica. Hierarchical sampling design used in this study. Five quadrats were nested within each of 2 areas, nested within each of 3 sites, nested within each of 3 meadows. Five replicate shoots were collected within

each quadrat

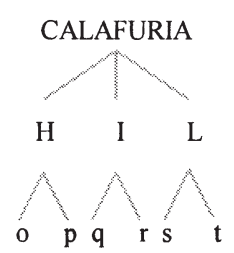

QUADRATS $123 \quad 3 \quad 45$

(m)

MEADOWS

SITES

AREAS

(10s m) 
water. The total number of samples was 450 (5 rhizomes $\times 5$ quadrats $\times 2$ areas $\times 3$ sites $\times 3$ meadows). Density of shoots (number of shoots $\mathrm{m}^{-2}$ ) was measured in situ by using 5 replicate $0.25 \mathrm{~m}^{2}$ quadrats randomly located in each of the 2 areas within each of 3 sites and meadows. All samplings and counting were carried out in late August 1999.

In the laboratory, leaves were removed from each shoot in distichous order of insertion and separated into the various categories defined by Giraud (1979). For each shoot, the following leaf traits were scored: (1) total number of standing leaves; (2) total number and (3) length of adult, intermediate and juvenile leaves; (4) leaf width and (5) length of the longest standing leaf (i.e. height of leaf canopy). The percentages of leaves having lost their apex due to herbivory or other causes than herbivores (Coefficient A) were also calculated. Leaf area index (LAI) was determined as product of leaf surface area (total leaf length per mean leaf width) by shoot density. For each shoot, leaves were oven-dried at $60^{\circ} \mathrm{C}$ for $3 \mathrm{~d}$ and weighed to the nearest $0.1 \mathrm{mg}$. Standing crop was determined as the dry weight of leaves $\mathrm{m}^{-2}$. All rhizomes collected were then examined to measure the rate of rhizome elongation ( $\mathrm{cm}$ per shoot and year) and leaf formation (number of leaves produced per shoot and year). Estimates were made by using lepidochronological analysis, according to standardised procedures (Pergent 1990).

Morphological and dynamic variables were separately analysed using nested analyses of variance (ANOVA) with meadow (3 levels), site (3 levels) within each meadow, area (2 levels) within each site and meadow, and quadrat (5 levels) within each area, site and meadow. For the structural variables, there were only 3 factors: meadow (3 levels), site (3 levels) within each meadow, and area (2 levels) within each site and meadow. All factors were random. To determine which scales are associated with the greatest variability, the components of variation on each spatial scale were estimated using ANOVA on untransformed data according to the methods described by Sokal \& Rohlf (1981) and Underwood (1997). Negative variance components were converted to 0 (Brown \& Mosteller 1991) under the assumption that they were underestimated samples of small or 0 variances (Searle et al. 1992). Moreover, the database was used to simulate one of the most frequently used sampling designs advocated to measure the morphological structural and dynamic features of Posidonia oceanica (Pergent et al. 1995, Fresi \& Dolce 2001), in order to draw possible inferences about meadows different from those obtained with the complete design. To do this, each site was considered as a 'station area' omitting the spatial scales, then the possible subsets of data, generated considering only one of the 3 potential station areas within each meadow, were analysed using a 1-way ANOVA. There were 27 subsets of combinations (3 station areas within each meadow $\times 3$ meadows) and 10 replicate quadrats or 50 replicate shoots (depending on the variable examined). The homogeneity of variance was examined using Cochran's $C$-test before running the analysis. Data were natural $\log$, $\arcsin (\%)$ or square-root transformed when necessary to normalise their distribution and to remove heteroscedasticity (Sokal \& Rohlf 1981, Underwood 1997).

\section{RESULTS}

All the variables considered showed significant differences in their mean values for at least one of the scales of the nested analyses, and 2 variables (rhizome elongation and length of adult leaves) differed at all scales (Tables 1 \& 2). Patterns of differences on various scales differed for each individual leaf trait. For example, while the mean number of total standing leaves only varied significantly on intermediate scale of 100 s of $\mathrm{m}$ (Fig. 2A), the number of adult leaves (Fig. 2B) varied on the scale of metres, that of intermediate leaves (Fig. 2C) on the scale of $10 \mathrm{~s}$ of $\mathrm{km}, 100 \mathrm{~s}$ of $\mathrm{m}$ and at the $\mathrm{m}$ scale only, and that of juvenile leaves (Fig. 2D) varied on the scale of $10 \mathrm{~s}$ of $\mathrm{km}$ and $10 \mathrm{~s}$ of m. Similarly, while the length of the longest leaf (Fig. 3A) varied on the most extreme scales investigated, i.e. 10s of $\mathrm{m}$ and $10 \mathrm{~s}$ of $\mathrm{km}$, the length of adult leaves (Fig. 3B) varied significantly on all the scales investigated, the length of intermediate leaves (Fig. 3C) on the scale of $10 \mathrm{~s}$ of $\mathrm{km}, 100 \mathrm{~s}$ of $\mathrm{m}$ and at the metres scale only, and that of juvenile leaves (Fig. 3D) varied only on the scale of $10 \mathrm{~s}$ of $\mathrm{km}$. Overall, at least 3 leaf traits differed on each scale, indicating that considerable variations in the rhythm of leaf appearance and/or that growth occurred among patches spaced from metres to $10 \mathrm{~s}$ of $\mathrm{km}$ apart. On the other hand, the percentages of broken and grazed leaves (Fig. 4A,B) were variable only on the scale of $10 \mathrm{~s}$ of $\mathrm{km}$, indicating differences in grazing pressure and hydrodynamic stress on a broad scale (i.e. among meadows). Among the structural variables, shoot density (Fig. 5A) varied only on an intermediate scale of 100 s of $\mathrm{m}$, standing crop (Fig. 5B) and LAI (Fig. 5C) varied at the scales of $10 \mathrm{~s}$ of $\mathrm{km}$ and $100 \mathrm{~s}$ of $\mathrm{m}$. Among the dynamic characteristics, the rate of rhizome elongation (Fig. 6A) varied on all the scales examined, while the annual rate of leaf formation (Fig. 6B) varied on the most extreme scales investigated, metres and $10 \mathrm{~s}$ of $\mathrm{km}$. Collectively, at the plant level, more significant differences were found on the most extreme of scales of $10 \mathrm{~s}$ of $\mathrm{km}$ (11 of the 12 analysed) and metres ( 7 of 12) than at intermediate 
Table 1. Posidonia oceanica. Summary of comparisons between meadows, sites, areas and quadrats for morphological variables using nested ANOVAs. Leaf lengths were measured in cm. interm.: intermediate

\begin{tabular}{|c|c|c|c|c|c|c|c|c|c|c|c|c|c|}
\hline \multirow{2}{*}{$\begin{array}{l}\text { Source of } \\
\text { variation }\end{array}$} & \multirow[t]{2}{*}{ df } & \multicolumn{3}{|c|}{ No. of standing leaves } & \multicolumn{3}{|c|}{ No. of adult leaves } & \multicolumn{3}{|c|}{ No. of interm. leaves } & \multicolumn{3}{|c|}{ No. of juvenile leaves } \\
\hline & & MS & $F$ & $\mathrm{p}$ & MS & $F$ & $\mathrm{p}$ & MS & $F$ & $\mathrm{p}$ & MS & $F$ & $\mathrm{p}$ \\
\hline Meadows & 2 & 0.657 & 2.09 & $>0.20$ & 7.046 & 2.16 & $>0.100$ & 44.868 & 13.99 & $<0.006$ & 19.886 & 7.900 & $<0.050$ \\
\hline Sites (M) & 6 & 0.314 & 6.66 & $<0.05$ & 3.264 & 2.89 & $>0.050$ & 3.206 & 3.44 & $<0.050$ & 2.517 & 1.720 & $>0.200$ \\
\hline Areas (S(M)) & 9 & 0.040 & 1.04 & $>0.40$ & 1.128 & 1.53 & $>0.100$ & 0.933 & 1.47 & $>0.100$ & 1.460 & 3.580 & $<0.001$ \\
\hline Quadrats $(\mathrm{A}(\mathrm{S}(\mathrm{M})))$ & 72 & 0.040 & 1.20 & $>0.10$ & 0.736 & 1.54 & $<0.005$ & 0.634 & 1.42 & $<0.050$ & 0.407 & 0.940 & $>0.300$ \\
\hline Residual & 360 & 0.030 & & & 0.477 & & & 0.446 & & & 0.432 & & \\
\hline \multirow{2}{*}{\multicolumn{2}{|c|}{$\begin{array}{l}\text { Cochran's } C \text {-test } \\
\text { Transformation }\end{array}$}} & \multicolumn{3}{|c|}{$C=0.07$} & \multicolumn{3}{|c|}{$C=0.05$} & \multicolumn{3}{|c|}{$C=0.05$} & \multicolumn{3}{|c|}{$C=0.04$} \\
\hline & & \multicolumn{3}{|c|}{ Square root $(x+1)$} & \multicolumn{3}{|c|}{ None } & \multicolumn{3}{|c|}{ None } & \multicolumn{3}{|c|}{ None } \\
\hline \multirow{2}{*}{$\begin{array}{l}\text { Source of } \\
\text { variation }\end{array}$} & \multirow[t]{2}{*}{$\mathrm{df}$} & \multicolumn{3}{|c|}{ Length of adult leaves } & \multicolumn{3}{|c|}{ Length of interm. leaves } & \multicolumn{3}{|c|}{ Length of juvenile leaves } & \multicolumn{3}{|c|}{ Length of longest leaf } \\
\hline & & MS & $F$ & $\mathrm{p}$ & MS & $F$ & $\mathrm{p}$ & MS & $F$ & $\mathrm{p}$ & MS & $F$ & $\mathrm{p}$ \\
\hline Meadows & 2 & 33834.751 & 26.31 & $<0.005$ & 909.284 & 13.80 & $<0.05$ & 5.499 & 10.76 & $<0.05$ & 5398.260 & 11.09 & $<0.050$ \\
\hline Sites (M) & 6 & 1285.998 & 3.88 & $<0.050$ & 65.898 & 3.58 & $<0.05$ & 0.511 & 0.89 & $>0.50$ & 486.740 & 1.99 & $>0.100$ \\
\hline Areas (S(M)) & 9 & 331.041 & 2.32 & $<0.050$ & 18.424 & 1.06 & $>0.40$ & 0.576 & 1.38 & $>0.20$ & 244.231 & 0.69 & $>0.700$ \\
\hline Quadrats $(\mathrm{A}(\mathrm{S}(\mathrm{M})))$ & 2 & 142.502 & 1.55 & $<0.050$ & 17.462 & 1.48 & $<0.05$ & 0.417 & 1.33 & $>0.05$ & 354.273 & 0.34 & $<0.001$ \\
\hline Residual & 360 & 91.898 & & & 11.773 & & & 0.314 & & & 1034.0230 & & \\
\hline Cochran's $C$-test & & \multicolumn{3}{|c|}{$\begin{array}{c}C=0.03 \\
\text { None }\end{array}$} & \multicolumn{3}{|c|}{$\begin{array}{c}C=0.05 \\
\text { None }\end{array}$} & \multicolumn{3}{|c|}{$\begin{array}{c}C=0.06 \\
\text { None }\end{array}$} & \multicolumn{3}{|c|}{$\begin{array}{c}C=0.024 \\
\text { None }\end{array}$} \\
\hline
\end{tabular}
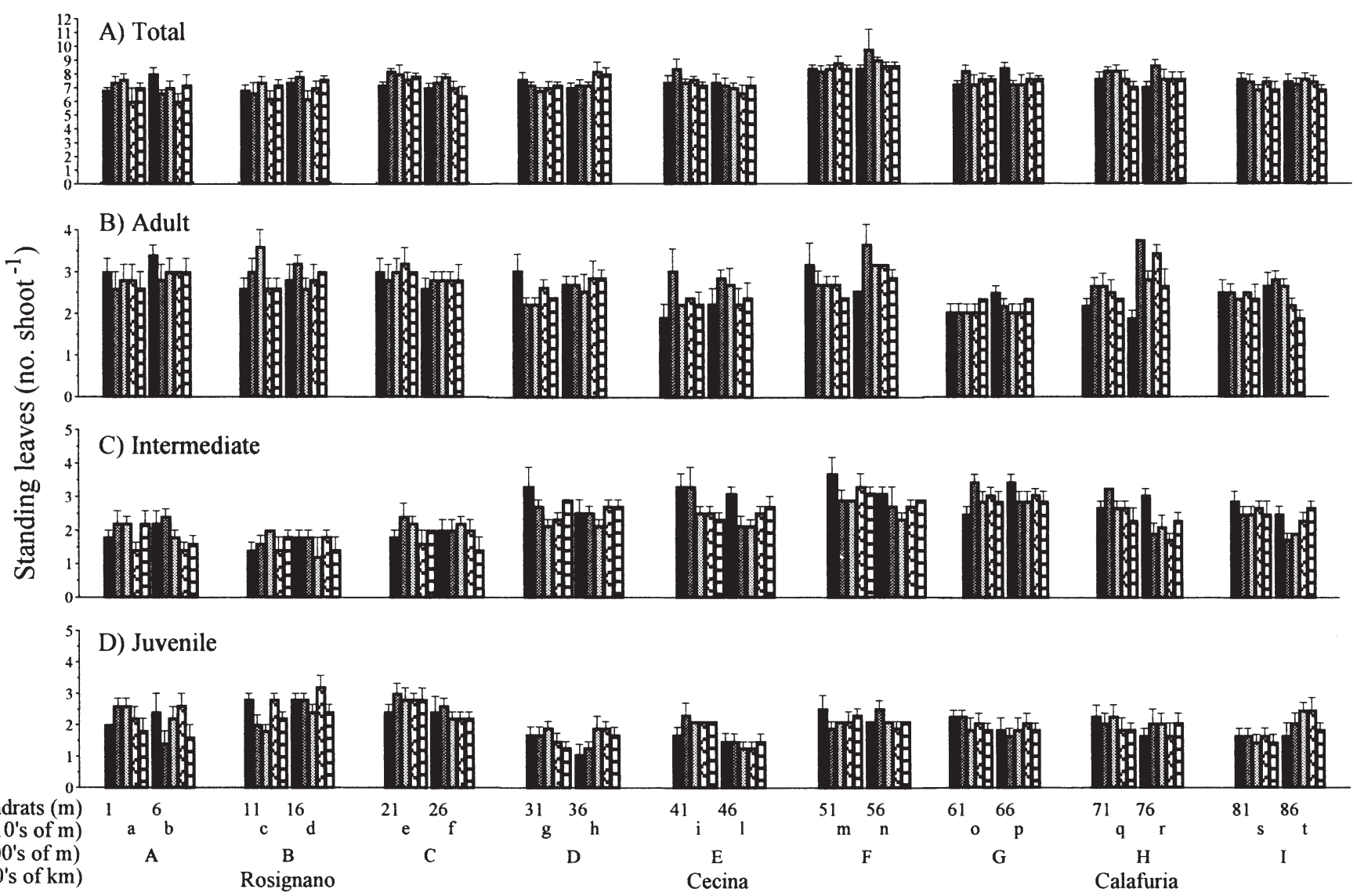

Fig. 2. Posidonia oceanica. Mean \pm SE numbers of (A) total standing leaves, (B) adult leaves, (C) intermediate leaves and (D) juvenile leaves per shoot $(n=5)$. There are 5 quadrats in each of 2 areas, in each of the 3 sites, in each of the 3 meadows 
Table 2. Posidonia oceanica. Summary of comparisons between meadows, sites, areas and quadrats for structural and dynamic variables using nested ANOVAs. LAI: leaf area index

\begin{tabular}{|c|c|c|c|c|c|c|c|c|c|c|c|c|c|}
\hline \multirow[t]{2}{*}{$\begin{array}{l}\text { Source of } \\
\text { variation }\end{array}$} & \multirow[t]{2}{*}{ df } & \multicolumn{3}{|c|}{$\begin{array}{l}\text { Leaf formation } \\
\left(\text { no. } \text { shoot }^{-1} \mathrm{yr}^{-1}\right)\end{array}$} & \multicolumn{3}{|c|}{$\begin{array}{c}\text { Broken leaves } \\
(\%)\end{array}$} & \multicolumn{3}{|c|}{$\begin{array}{c}\text { Grazed leaves } \\
(\%)\end{array}$} & \multicolumn{3}{|c|}{$\begin{array}{l}\text { Rhizome elongation } \\
\quad\left(\mathrm{cm} \mathrm{shoot}^{-1} \mathrm{yr}^{-1}\right)\end{array}$} \\
\hline & & MS & $F$ & $\mathrm{p}$ & MS & $F$ & $\mathrm{p}$ & MS & $F$ & $\mathrm{p}$ & MS & $F$ & $\mathrm{p}$ \\
\hline Meadows & 2 & 0.547 & 35.32 & $<0.005$ & 7532.433 & 25.50 & $<0.005$ & 3108.775 & 45.16 & $<0.001$ & 10.124 & 6.86 & $<0.050$ \\
\hline Sites (M) & 6 & 0.015 & 1.27 & $>0.300$ & 295.399 & 2.65 & $>0.050$ & 68.837 & 1.67 & $>0.200$ & 1.476 & 4.18 & $<0.050$ \\
\hline Areas (S(M)) & 9 & 0.012 & 1.35 & $>0.200$ & 111.590 & 0.77 & $>0.600$ & 41.314 & 0.38 & $>0.900$ & 0.353 & 3.48 & $<0.005$ \\
\hline Quadrats (A(S(M))) & 72 & 0.009 & 1.55 & $<0.050$ & 144.462 & 1.32 & $>0.050$ & 108.681 & 0.86 & $>0.200$ & 0.101 & 1.68 & $<0.050$ \\
\hline Residual & 360 & 0.005 & & & 109.825 & & & 126.295 & & & 0.060 & & \\
\hline Cochran's $C$-test & & & $C=0.06$ & & & $C=0.03$ & & & $C=0.02$ & & & $C=0.0$ & \\
\hline Transformation & & & $\operatorname{Ln}(x)$ & & & $\mathrm{rcsin}(\%$ & & & $\mathrm{rcsin}(\%$ & & & $\operatorname{Ln}(x)$ & \\
\hline \multirow[t]{2}{*}{$\begin{array}{l}\text { Source of } \\
\text { variation }\end{array}$} & \multirow[t]{2}{*}{ df } & \multicolumn{3}{|c|}{$\begin{array}{l}\text { Shoot density } \\
\left(\text { no. shoots } \mathrm{m}^{-2} \text { ) }\right.\end{array}$} & \multicolumn{3}{|c|}{ LAI } & \multicolumn{3}{|c|}{ 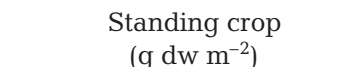 } & & & \\
\hline & & MS & $F$ & $\mathrm{p}$ & MS & $F$ & $\mathrm{p}$ & MS & $F$ & $\mathrm{p}$ & & & \\
\hline Meadows & 2 & 22300.900 & 1.34 & $>0.300$ & 78.200 & 4.94 & $<0.05$ & 454785.361 & 5.69 & $<0.050$ & & & \\
\hline Sites (M) & 6 & 16660.167 & 11.21 & $<0.005$ & 15.385 & 4.53 & $<0.05$ & 79963.050 & 15.51 & $<0.005$ & & & \\
\hline Areas (S(M)) & 9 & 1485.922 & 0.45 & $>0.900$ & 3.497 & 1.12 & $>0.30$ & 5917.486 & 0.64 & $>0.500$ & & & \\
\hline Residual & 72 & 3321.288 & & & 3.129 & & & 9242.18 & & & & & \\
\hline Cochran's $C$-test & \multirow{2}{*}{\multicolumn{4}{|c|}{$\begin{array}{c}C=0.15 \\
\text { None }\end{array}$}} & \multirow{2}{*}{\multicolumn{3}{|c|}{$\begin{array}{c}C=0.22 \\
\text { None }\end{array}$}} & \multirow{2}{*}{\multicolumn{3}{|c|}{$\begin{array}{c}C=0.19 \\
\text { None }\end{array}$}} & & & \\
\hline Transformation & & & & & & & & & & & & & \\
\hline
\end{tabular}
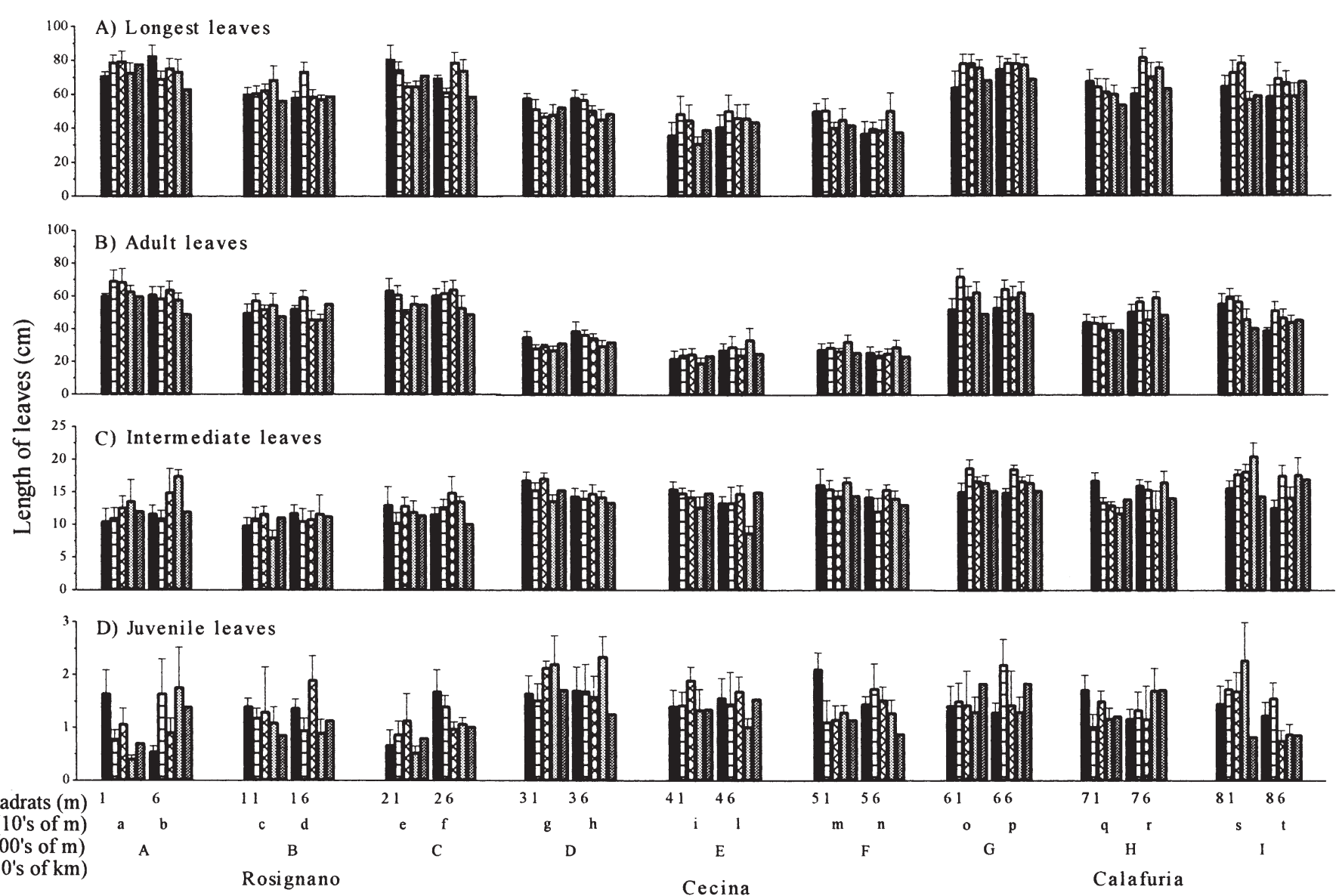

Fig. 3. Posidonia oceanica. Mean \pm SE lengths of (A) longest leaves, (B) adult leaves, (C) intermediate leaves and (D) juvenile leaves per shoot $(n=5)$. There are 5 quadrats in each of 2 areas, in each of the 3 sites, in each of the 3 meadows 


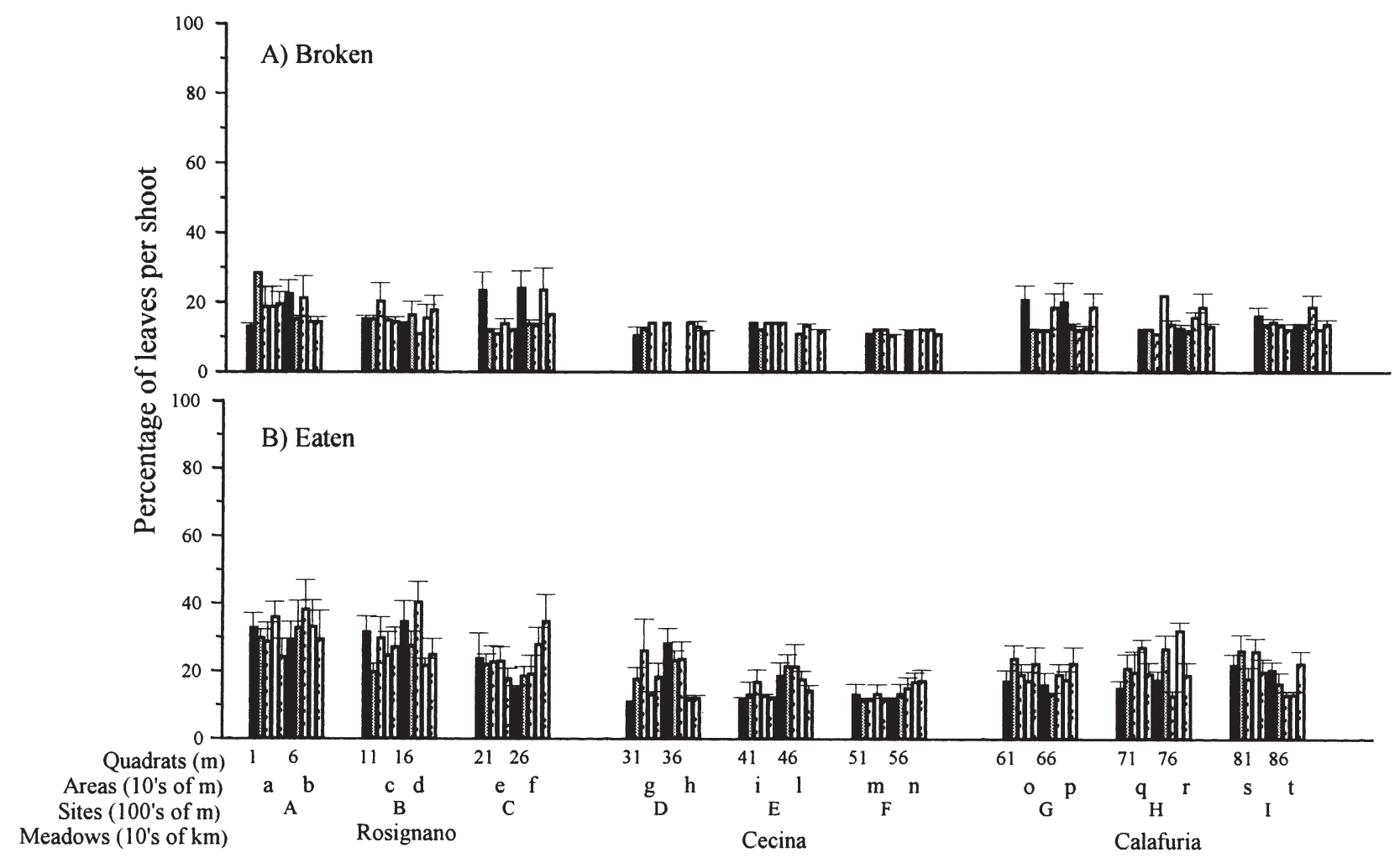

Fig. 4. Posidonia oceanica. Mean \pm SE percentages of $(A)$ broken leaves and (B) eaten leaves per shoot $(n=5)$. There are 5 quadrats in each of 2 areas, in each of the 3 sites, in each of the 3 meadows
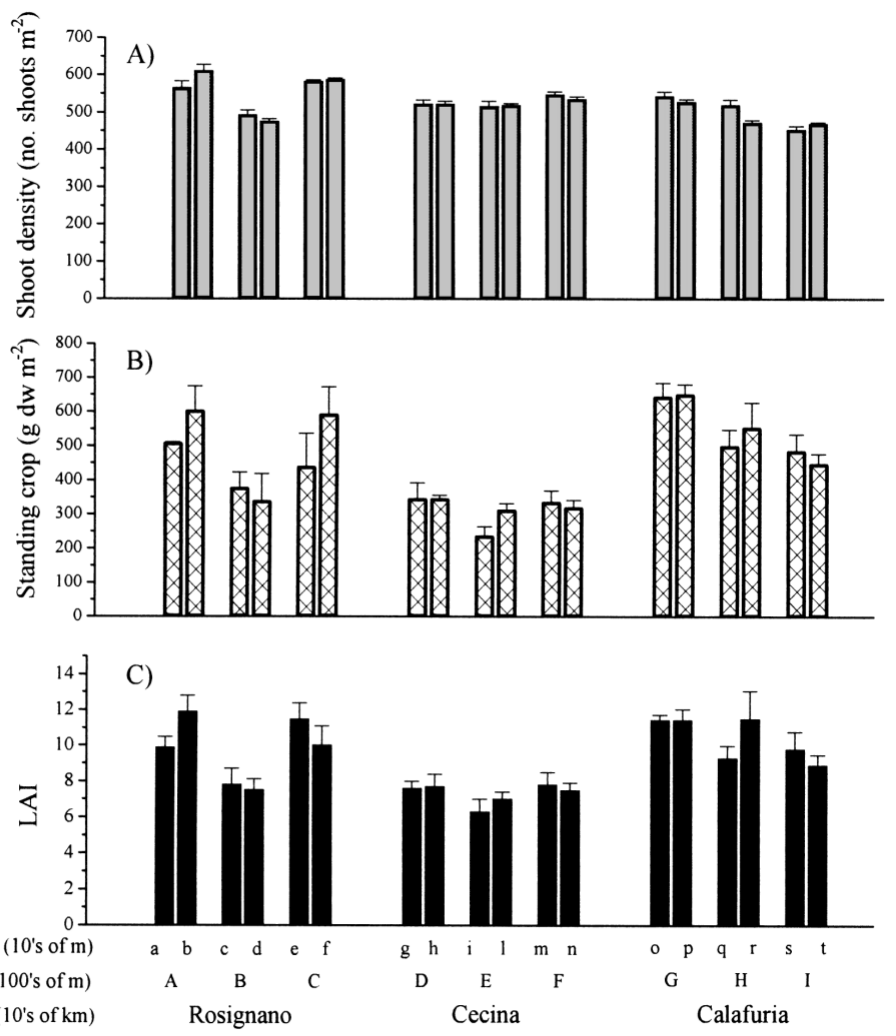

Fig. 5. Posidonia oceanica. Mean \pm SE of (A) shoot densities, (B) standing crops and (C) leaf area index (LAI). There are 5 quadrats in each of 2 areas, in each of 3 sites, in each of the 3 meadows scales of 100s of $\mathrm{m}$ (5 of 12) and 10s of m (3 of 12). At the meadow level, more significant differences on the scale of $10 \mathrm{~s}$ of $\mathrm{km}$ (2 of 3 ) and $100 \mathrm{~s}$ of $\mathrm{m}$ ( 3 of 3$)$, than on the smallest scales of metres (0 of 3 ) were observed. Components of variation calculated on each of the spatial scales investigated (Fig. 7) indicated that the within-quadrat scale (i.e. among shoots) at the plant level or the within-area scale (i.e. among quadrates) at the meadow level (i.e. the residual mean squares) were the most important in explaining total variances. There was also evidence of significant variation associated with the largest scale (i.e. $10 \mathrm{~s}$ of $\mathrm{km}$ among meadows) for some variables. Finally, the scale of $10 \mathrm{~s}$ of $\mathrm{m}$ was the least important source of variation for all variables examined ( 0 to $17 \%$ of total variance).

For a number of variables and combinations, analyses of data simulating a simple sampling design showed results opposite to those of the complete nested design. Significant differences among meadows were detected in shoot density, total number of standing leaves and number of adult leaves, respectively, in 17, 19 and 6 of the 27 possible combinations. No significant differences among meadows were detected in the number and length of juvenile leaves, respec- 


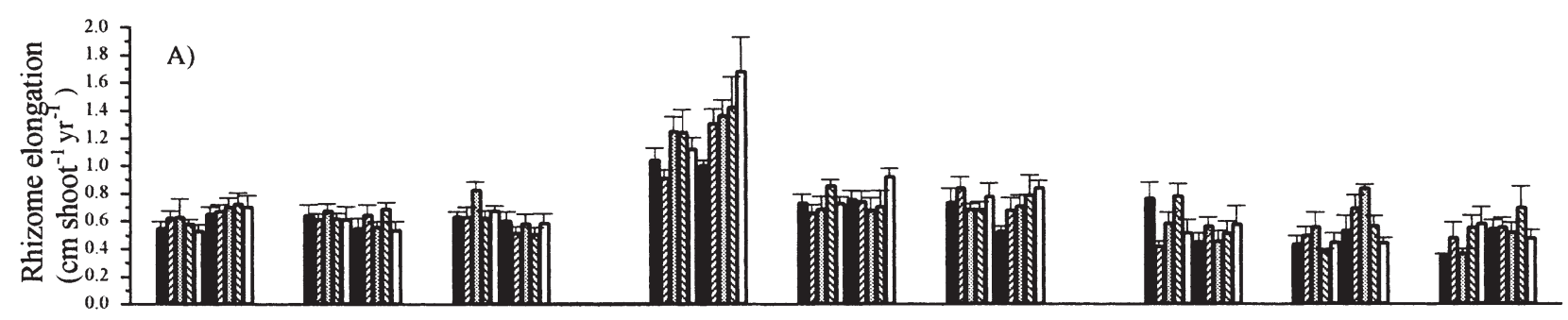

B)

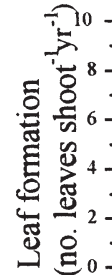

Quadrats $(m)$

$\operatorname{Areas}(10$ 's of $\mathrm{m})$

Sites (100's of m)

Meadows (10's of km)

Fig. 6. Posidonia oceanica. Mean $\pm \mathrm{SE}$ annual rates of $(\mathrm{A})$ rhizome elongation and (B) leaf formation per shoot $(\mathrm{n}=5)$. There are 5 quadrats in each of 2 , areas in each of the 3 sites, in each of the 3 meadows

tively, in 3 and 11 of the 27 possible combinations. Conversely, for the remainder variables, the results showed significant differences according to the nested design, but the a posteriori multiple comparison test (Student-Newman-Keuls) identified different alternative hypotheses in 2 (percentage of broken and eaten leaves), 9 (LAI), 11 (number of intermediate leaves and length of adult leaves), 14 (maximum leaf length), 18 (standing crop), 19 (rhizome elongation), 20 (length of intermediate leaves) and 21 (leaf formation) of 27 combinations.

\section{DISCUSSION}

The present study provides detailed evidence that substantial differences in basic structural, morphological and dynamic characteristics used as indicators of the status of Posidonia oceanica meadows occurred at a variety of spatial scales, within individual meadows and among meadows separated by $10 \mathrm{~s} \mathrm{~km}$, along the same isobath. It also suggests that patchiness exists on a smaller spatial scale than that of metres (i.e. among shoots for morphological and growth variables) or $10 \mathrm{~s}$ of $\mathrm{m}$ (i.e. among quadrats for structural variables), indicating that very local changes in habitat quality may affect growth and morphology of $P$. oceanica even at the same depth. Our findings, although preliminary, demonstrate the importance of carrying out sampling at more than 1 scale when studying $P$. oceanica meadows. Considerable care is required when using simple sampling procedures in order to draw inferences on the status and/or trends of $P$. oceanica meadows. As recently pointed out by several ecologists, there is a risk of incorrect generalization of studies on biological variables over large spatial scales in heterogeneous habitats, whenever the within-location variability resulting from small-scale patchiness is not adequately taken into account in the sampling procedure (Underwood 1981, 1991, 1996, Wiens et al. 1986, Morrisey et al. 1992, Underwood \& Petraitis 1993, Schenider 1994, Hewitt et al. 1998, Kendall \& Widdicombe 1999). This study extrapolated data from means of replicate quadrats or shoots at only 1 station area within each $P$. oceanica meadow to the whole meadow been used, then misleading results would have arisen. For example, we would have concluded that there were among meadow differences in several features, where in fact there were not, thus committing a Type-I error (i.e. rejecting the null hypothesis when it is true), and in addition, that there were no differences for other features when there indeed were, thus committing a Type-II error (i.e. accepting the null hypothesis when it is false). Such an approach might not provide an adequate or representative description on the status of a particular $P$. oceanica meadow and prevent valid comparisons among meadows, because any difference observed among meadows might be confused with simple variation due to stochastic variability from one station to another within the meadows. The problem of lack of appreciation of within-meadow variation could also occur in studies which seek to examine the same meadow over time; it is difficult to determine whether the observed changes reflect real temporal differences or simply a problem with the sampling design, as samples could come from different patches within the 

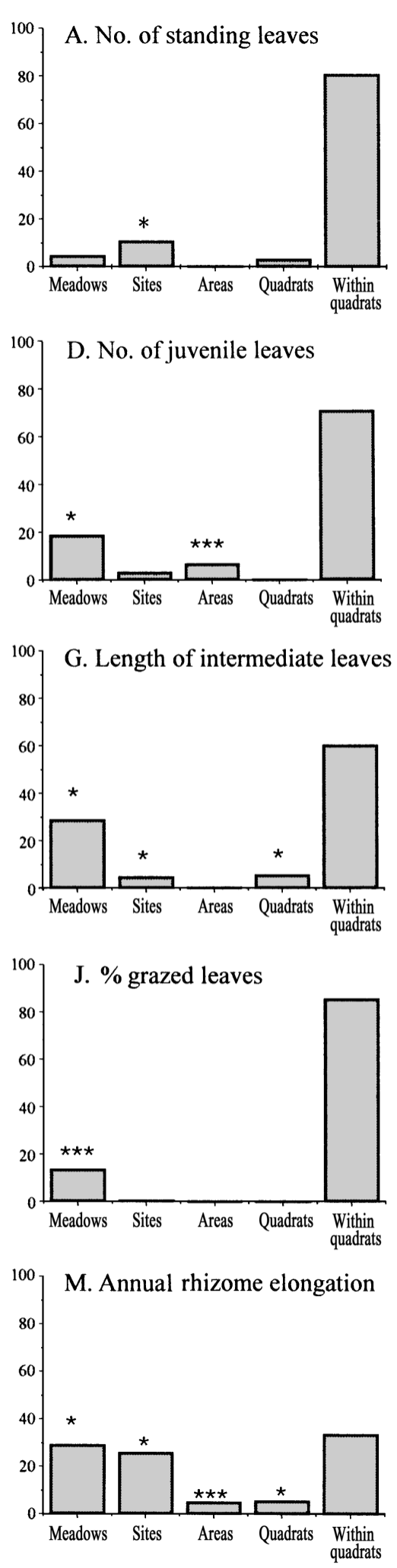
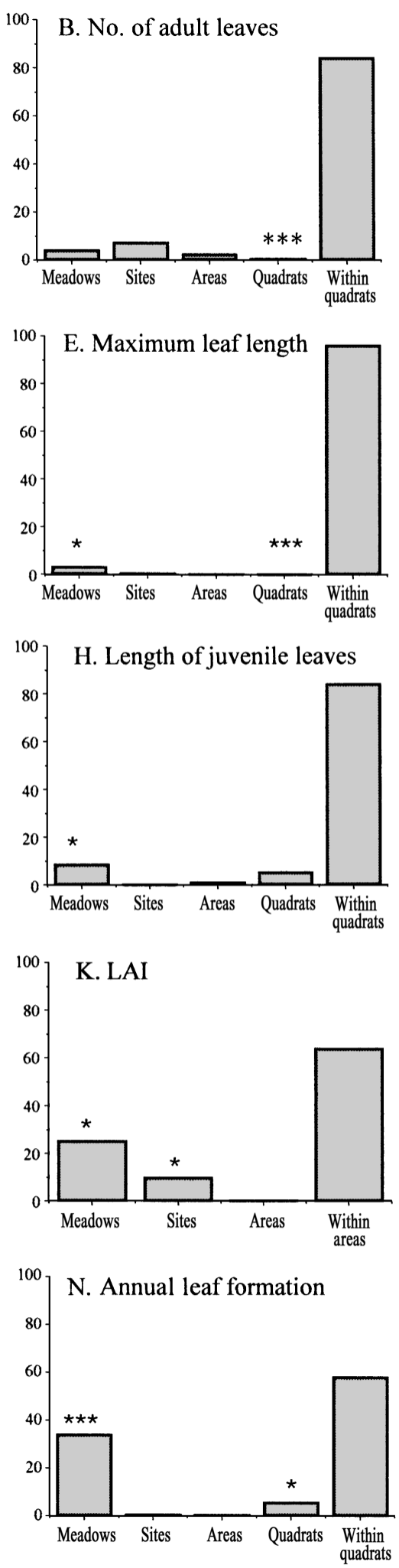
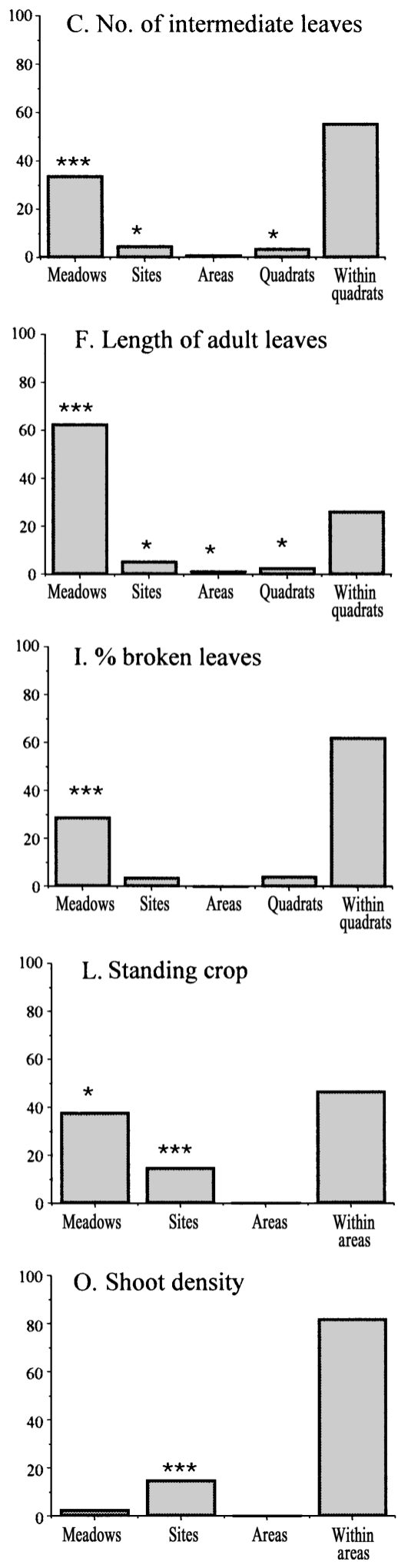

Fig. 7. Posidonia oceanica. Components of variation at 5 spatial scales (A) to (O) show variation in different factors (see headings). LAI: leaf area index. Overall variation is partitioned among scales and expressed as a percentage of the total. Negative variance components were converted to 0. Asterisks indicate the spatial scales where significant differences occurred among meadows, sites, areas, quadrats, within quadrats or within areas. ${ }^{*} \mathrm{p}<0.05,{ }^{* *} \mathrm{p}<0.01,{ }^{* * *} \mathrm{p}<0.001$ 
meadow each time. Our conclusions are based on a single sampling occasion and on a survey of meadows at 3 locations within a region; further research is obviously needed to assess these points.

The results of this study also allow formulation of several hypotheses concerning factors that may account for the observed patterns in morphology and growth of Posidonia oceanica. Variations on the largest scale (meadows 10 s of $\mathrm{km}$ apart) might reflect differences in the type of habitats at the localities, such as wave exposure, substrate type (rocky vs pebble), sediment characteristics and grazing pressure, whenever other potentially important factors, such as temperature and photoperiod (Alcoverro et al. 1997), are virtually identical. Within these patterns, other factors, such as physical disturbance, topographic complexity and nutrient availability, might operate on smaller scales to modify morphological and growth variables. The variation observed on the smaller scale ( $\mathrm{cm}$ to $\mathrm{m}$ ) is more difficult to explain. It might be attributable to unidentifiable nested components of variation (Underwood 1997) and differences in the microhabitat. Further spatial statistical techniques (e.g. spatial autocorrelation) and measurements of physical and chemical variables within meadows are clearly needed to identify the factors causing small-scale patchiness. On the other hand, for the scope of this and similar studies, there is only the need to recognise that a spatial pattern exists, no matter why, as pointed by Underwood (1997).

In conclusion, we believe that a more rigorous approach should be used in the future when planning large-scale or long-term investigations. Nested designs that incorporate different spatial scales within a particular stratum (i.e. range of depth) would be particularly useful as they may provide unbiased estimates of the status of Posidonia oceanica meadows. They also permit cost/benefit analyses to be applied to ensure optimal allocation sampling efforts over space and time, and can thus promote the development of efficient large-scale $P$. oceanica surveys, including monitoring strategies (Underwood 1981, 1997, Andrew \& Mapstone 1987, Morrisey et al. 1992, Schenider 1994). Since some of the implications described above for $P$. oceanica could be valid for other seagrass species, it would be interesting to examine whether the patterns of spatial variability in morphological and dynamic characteristics observed are a common feature of seagrasses.

Acknowledgements. We thank L. Benedetti-Cecchi for substantial help with the statistical analysis, and G. Marino, F. Vallerini and S. Bertini for sampling. We also thank 2 anonymous referees for their substantial contribute to the improvement of the manuscript. The study was in part supported by Solvay \& Cie Industry (Rosignano Solvay, Italy).

\section{LITERATURE CITED}

Alcoverro T, Duarte CM, Romero J (1995) Annual growth dynamics of Posidonia oceanica: contribution of largescale versus local factors to seasonality. Mar Ecol Prog Ser 120:203-210

Alcoverro T, Romero J, Duarte CM, López NI (1997) Spatial and temporal variations in nutrient limitation of seagrass Posidonia oceanica growth in the NW Mediterranean. Mar Ecol Prog Ser 146:155-161

Andrew NL, Mapstone BD (1987) Sampling and the description of spatial pattern in marine ecology. Oceanogr Mar Biol Annu Rev 25:39-90

Ardizzone GD, Pelusi P (1984) Yield and damage evaluation of bottom trawling on Posidonia oceanica meadows. In: Boudouresque CF, Jeudy de Grissac A, Olivier J (eds) International workshop on Posidonia oceanica beds. GIS Posidonie, Marseille, p 63-72

Augier H, Gilles G, Ramonda G (1984) L'herbier de Posidonia oceanica et la pollution par le mercure sur le littoral des Bouches-du-Rhone et du Var (France). In: Boudouresque CF, Jeudy de Grissac A, Olivier J (eds) International workshop on Posidonia oceanica beds. GIS Posidonie, Marseille, p 399-406

Benedito V, Torres J, Giner IM, Esteban JL, Capaccioni R, Garcia-Carrascosa AM (1990) Distribution and preliminary evaluation of the state of the Posidonia oceanica in the coasts of the Gulf of Valencia (Spain, western Mediterranean). Rapport Commission International par l'exploration scientifique de la mer mediterranée Monaco, Vol 32(1) p 8

Boudouresque CF, Pergent G, Francour P, Harmelin-Vivien $\mathrm{M}$ and 7 others (1990) Le COST 647: Posidonia project. Posidonia Newslett 3:27-34

Bourchier M (1989) Regression des herbiers à Posidonia oceanica (L.) Delile, a l'est de Marseille, sous l'action conjugée des activities humaines et des modification climatique. In: Boudouresque CF, Meinesz A, Fresi E, Gravez V (eds) International workshop on Posidonia oceanica beds. GIS Posidonie, Marseille, p 287-292

Brown C, Mosteller F (1991) Components of variance. In: Hoaglin DC, Mosteller F, Tukey JW (eds) Fundamentals of exploratory analysis. Wiley-Liss, New York, p 59-84

Burdick DM, Kendrick GA (2001) Standards for seagrass collection, identification and sample design. In: Short FT, Coles RG, Short CA (eds) Global seagrass research methods. Elsevier, Amsterdam, p 79-99

Cinelli F, Piazzi L (1991) Mappatura delle praterie a Posidonia oceanica (L.) Delile lungo le coste toscane. Relazione tecnica. Consorzio per il Centro Interuniversitario di Biologia Marina di Livorno

Duarte MC (1991) Variance and the description of nature: In: Cole JJ (ed) Comparative ecology of ecosystems: patterns mechanisms and theories. Springer-Verlag, Heidelberg, p 301-318

Erftemeijer PLA, Herman PMJ (1994) Seasonal changes in environmental variables, biomass, production and nutrient contents in 2 contrasting tropical interdital seagrass beds in South Sulawesi, Indonesia. Oecologia 99:45-59

Fonseca MS, Bell S (1998) Influence of physical setting on seagrass landscape near Beaufort, north Carolina, USA. Mar Ecol Prog Ser 171:109-201

Fresi E, Dolce T (2001) Monitoraggio del limite inferiore delle praterie di Posidonia oceanica. In: Cicero AM, Di Girolamo I (eds) Metodologie analitiche di riferimento. Programma di monitoraggio per il controllo dell'ambiente marino-costiero (triennio 2001-2003). Ministero dell'- 
Ambiente e della Tutela del Territorio-ICRAM. Lo Studio Editoriale s.r.l., Roma, p 1-4

Giraud G (1979) Sur une méthode de mesure et de comptage des structures foliares de Posidonia oceanica L. Delile. Bull Mus Hist Nat Mars 39:33-39

Guidetti P (2001) Detecting environmental impacts on the Mediterranean seagrass Posidonia oceanica (L.) Delile: the use of reconstructive methods in combination with 'beyond BACI' designs. J Exp Mar Biol Ecol 260:27-39

Guidetti P, Fabiano M (2000) The use of lepidochronology to assess the impact of terrigenous discharges on the primary leaf production of the Mediterranean seagrass Posidonia oceanica. Mar Pollut Bull 40(5):449-453

Hewitt JE, Thrush VJ, Cummings SJ, Turner SJ (1998) The effects of changing sampling scale on our ability to detect effects of large-scale processes on communities. J Exp Mar Biol Ecol 227:251-264

Inglis GJ, Lincoln Smith MP (1995) Choosing appropriate scales for ecological monitoring programmes: an estuarine case study. In: Bellwood O, Choat JH, Saxena N (eds) Recent advances in marine science and technology '94. James Cook University of North Queensland, Townsville, p 171-181

Kendall MA, Widdicombe S (1999) Small-scale patterns in the structure of macrofaunal assemblages of shallow soft sediments. J Exp Mar Biol Ecol 237:127-140

Levin SA (1992) The problem of pattern and scale in ecology. Ecology 73:1943-1967

Marbà N, Duarte CM (1995) Coupling of seagrass (Cymodocea nodosa) patch dynamics to subaqueous dune migration. J Ecol 83:381-389

Marbà N, Duarte CM (1997) Interannual changes in seagrass (Posidonia oceanica) growth and environmental change in the Spanish Mediterranean littoral zone. Limnol Oceanogr 42(5):800-810

Marbà N, Cebrián J, Enrìquez S, Duarte CM (1994) Migration of large sub aqueous bedforms measured using seagrasses (Cymodocea nodosa) as tracers. Limnol Oceanogr 39: 126-133

Marbà N, Duarte CM, Cebrian J, Galegos ME, Olesen B, Sand-Jensen K (1996) Growth and population dynamics of Posidonia oceanica on the Spanish Mediterranean coastelucidating seagrass decline. Mar Ecol Prog Ser 137: 203-213

Morrisey DJ, Howitt L, Underwood AJ, Stark JS (1992) Spatial variation in soft-sediment benthos. Mar Ecol Prog Ser 81: 197-204

Panayotidis P, Boudouresque CF, Marcot-Coqueugniot (1981) Microstructure de l'herbier de Posidonia oceanica (Linnaeus) Delile. Bot Mar 24(3):115-124

Patriquin DG (1975) Migration of blowouts in seagrass beds at Barbados and Carriacou, West Indies, and its ecological and geological implications. Aquat Bot 1:163-189

Peirano A, Bianchi NC (1995) Decline of the seagrass Posidonia oceanica in response to environmental disturbance: a simulation-like approach off Liguria (NW Mediterranean Sea). Proc 30th Europ Mar Biol Symp, Southampton, September 1995, p 87-95

Pérès JM, Picard J (1964) Nouveau manuel de bionomie bentique de la Méditerranée. Recl Trav Stn Mar Endoume Fac Sci Mars 31:1-137

Pergent G (1990) Lepidochronological analysis in the seagrass Posidonia oceanica: a standardized approach. Aquat Bot 37:39-54

Pergent G (1991) Les indicateurs écologique de la qualité du mileu marin en Mediterranée. Oceanis 17(4):341-350
Pergent G, Pergent-Martini C, Boudouresque CF (1995) Utilization de l'herbier a Posidonia oceanica comme l'indicateur biologique de la qualitè du milieu littoral en Mediterrannée: état des connoissances. Mesogée 54:3-27

Pergent G, Mendez S, Pergent-Martini C, Pasqualini V (1999) Preliminary data on the impact of fish farming facilities on Posidonia oceanica. Oceanol Acta 22:95-107

Pergent-Martini C, Rico-Raimondino V, Pergent G (1994) Primary production of Posidonia oceanica in the Mediterranean Basin. Mar Biol 120:9-15

Robbins BD, Bell SS (1994) Seagrass landscapes: a terrestrial approach to the marine subtidal environment. Trends Ecol Evol 9(8):301-304

Romero J, Pergent G, Pergent-Martini C, Mateo MA, Regnier C (1992) The detritic compartment in a Posidonia oceanica meadow: litter features, decomposition rates and mineral stocks. Mar Ecol 13(1):73-83

Schneider DC (1994) Quantitative ecology: spatial and temporal scaling. Academic Press, San Diego

Searle SR, Casell G, McCulloch CE (1992) Variance components. Wiley-Liss, New York

Sokal RR, Rohlf FJ (1981) Biometry. WH Freeman, New York

Townsend EC, Fonseca MS (1998) Bioturbation as a potential mechanism influencing spatial heterogeneity of north Carolina seagrass beds. Mar Ecol Prog Ser 169:123-132

Turner MG, Thrush SF, Wilkinson MR, Hewitt JE, Cummings VJ, Schwarz AM, Morrisey DJ, Hawes I (1996) Patch dynamics of the seagrass Zostera novazelandica at 3 sites in New Zealand. In: Kuo J, Walker DI, Kirkman H (eds) International workshop on seagrass biology, Rottnest Island. University of Western Australia, Perth, p 21-31

Underwood AJ (1981) Techniques of analysis of variance in experimental marine biology an ecology. Oceanogr Mar Biol Annu Rev 19:513-605

Underwood AJ (1991) Spatial and temporal problems with monitoring. In: Calow P, Petts GE (eds) Rivers handbook, Vol 2. Blackwell Scientific, Oxford, p 101-123

Underwood AJ (1993) The mechanisms of spatially replicated sampling programmes to detect environmental impacts in a variable word. Aust J Ecol 18:145-178

Underwood AJ (1996) Spatial patterns of variance in density of intertidal populations. In: Floyd RB, Shepard AW, De Barro PJ (eds) Frontiers of population ecology. CSIRO Publishing, Melbourne, p 369-389

Underwood AJ (1997) Experiments in ecology: their logical design and interpretation using analysis of variance. Cambridge University Press, Cambridge

Underwood AJ, Petraitis (1993) Structure of interdital assemblages in different locations: how can local processes be compared? In: Ricklefs R, Schulter D (eds) Species diversity in ecological communities. University of Chicago Press, Chicago, p 38-51

van Tussenbroek BI (1995) Thalassia testidinum leaf dynamics in a Mexican Caribbean coral reef lagoon. Mar Biol 122: $33-40$

Wiens J, Addicot J, Case T, Diamond J (1986) Overview: the importance of spatial and temporal scale in ecological investigations. In: Diamond J, Case T (eds) Community ecology. Harper \& Row, New York, p 143-153

Wijesinghe DK, Hutchings MJ (1997) The effects of spatial scale of environmental heterogeneity on the growth of a clonal plant: an experimental study with Glechoma hederacea. J Ecol 85:17-28

Zupo V, Buia MC, Mazzella L (1997) A production model for Posidonia oceanica based on temperature. Estuar Coast Shelf Sci 44:483-492 